\title{
Supraglottic Cancer pT3 TNM Finding v6
}

National Cancer Institute

\section{Source}

National Cancer Institute. Supraglottic Cancer pT3 TNM Finding v6. NCI Thesaurus. Code C64738.

Suprag lottic cancer with tumor limited to larynx with vocal cord fixation and/or invading any of the following: postcricoid area, pre-epiglottic tissues, paraglottic space, and/or minor thyroid cartilage erosion (e.g. inner cortex). (from AJCC 6th Ed.) 